\title{
KEMAMPUAN PEMECAHAN MASALAH DALAM FISIKA DENGAN PEMBELAJARAN GENERATIF BERBANTUAN SCAFFOLDING DAN ADVANCE ORGANIZER
}

\author{
Prelia Dwi Amanah, Ahmad Harjono, I Wayan Gunada \\ Program Studi Pendidikan Fisika \\ Universitas Mataram \\ Mataram, Indonesia \\ Email:preliada@gmail.com
}

\begin{abstract}
Generative learning has an advantage in the process of receiving new knowledge, so that learners need a medium in understanding a phenomenon that occurs. This research can help in dealing with the problem of scaffolding and advance organizers. The population in this study is all students of class XI SMA Negeri 4 Mataram academic year 2016/2017. Sampling was done by purposive sampling technique, and this quasi experimental study used non-equivalent group design design with pre-test and post test. The results obtained from the class given generative treatment scaffolding assisted and advanced organizer have the same increase. In both classes expected the same as the previous ability, but the difference between the two is not much different. Therefore, there is no effect of generative learning model with scaffolding and advance organizer on ability.
\end{abstract}

Keywords: generative learning, problem solving, scaffolding, advanve organizer.

\section{PENDAHULUAN}

Ilmu sangatlah penting dalam kehidupan, dengan ilmu kegiatan dan kebutuhan sehari-hari akan menjadi lebih mudah dan bermakna. Ilmu Pengetahuan Alam (sains) merupakan suatu cabang ilmu untuk mengetahui keteraturan alam untuk menguasai pengetahuan, baik fakta, konsep, prinsip, proses penemuan maupun suatu sikap ilmiah, dan fisika merupakan salah satu dari cabang ilmu tersebut. (Gunawan, 2015). Fisika merupakan bagian dari sains yang memfokuskan kajiannya pada materi, energi, dan hubungan antara keduanya (Gunawan et al, 2015).

Dewasa ini, kemampuan pemecahan masalah fisika peserta didik masih sangat kurang. Berdasarkan hasil observasi rendahnya hasil belajar fisika peserta didik kelas XI IPA SMA Negeri 4 Mataram didukung oleh nilai rata-rata ujian tengah semester (UTS) yang memiliki rentang nilai yang kecil dengan Kriteria Ketuntasan Minimum (KKM). Hasil belajar fisika peserta didik yang demikian patut diduga terjadi karena kurangnya kemampuan pemecahan masalah fisika peserta didik. Berdasarkan permasalahan tersebut, maka diperlukan model pembelajaran yang mampu melibatkan peserta didik secara aktif sehingga pembelajaran menjadi lebih bermakna. Permasalahan ini dapat diselesaikan dengan menggunakan model pembelajaran yang sesuai dengan kemampuan peserta didik.
Model pembelajaran yang dapat menjadi solusi menurut peneliti patut diduga adalah model pembelajaran generatif. Model pembelajaran generatif merupakan salah satu model pembelajaran yang berpusat pada peserta didik yang memungkinkan aktif dalam berinteraksi, sehingga peserta didik akan menemukan konsep baru dengan pengintegrasian pengetahuan yang dimiliki sebelumnya dan belajarpun menjadi bermakna. Hal ini sejalan dengan pendapat Hamdani (2012) bahwa model pembelajaran generatif ini bertujuan untuk memperkenalkan konsep dan dapat mengadopsi informasi baru terhadap apa yang mereka telah ketahui. Selain itu, hal ini juga diperkuat dari hasil penelitian sebelumnya yaitu Sugiana et al (2016) mengatakan bahwa terdapat pengaruh penguasaan konsep fisika peserta didik antara kelas eksperimen yang diberikan perlakuan berupa penggunaan model pembelajaran generatif berbantuan media laboratorium virtual. Sintak yang digunakan dalam model tersebut ada 4 yaitu persiapan, pemfokusan, tantangan, dan aplikasi. Sintak pembelajaran generatif tersebut diharapkan dapat membimbing peserta didik menemukan konsep baru dari kegiatan pembelajaran, sehingga kemampuan pemecahan masalah peserta didik meningkat.

Selain dengan menerapkan model pembelajaran generatif, peserta didik diduga akan lebih mudah dalam memecahkan masalah bila 
diberi bantuan scaffolding. Berdasarkan teori belajar Vygotsky tentang zona perkembangan proksimal, membahas jarak antara tingkat perkembangan aktual dengan tingkat perkembangan potensial dapat dilakukan dengan pemberian scaffolding. Menurut Katminingsih dalam Septriani et al (2014) menyatakan bahwa scaffolding adalah memberikan kepada seorang anak, sejumlah besar bantuan selama tahap-tahap awal pembelajaran dan kemudian mengurangi bantuan tersebut dan memberikan kesempatan kepada anak tersebut mengambil alih tanggung jawab yang semakin besar segera setelah mampu mengerjakan sendiri, sehingga peserta didik tersebut dapat memecahkan masalahnya sendiri. Penelitian terkait scaffolding yaitu Rahmatiah et al (2016) menyatakan bahwa strategi scaffolding konseptual dalam pembelajaran Group Investigation dapat meningkatkan prestasi belajar Fisika peserta didik.

Selain scaffolding, bantuan berupa advance organizer diduga dapat membantu peserta didik dalam belajar. Hasil kajian dari 56 dokumen, menurut Cotton dalam Tasiwan et al (2014) menyatakan bahwa advance organizer merupakan salah satu strategi pembelajaran yang mampu meningkatkan kemampuan berpikir tingkat tinggi meliputi kemampuan menganalisa, mensintesa dan evaluasi. Advance organizer berfungsi dalam memberikan dukungan untuk informasi baru untuk memudahkan menghubungkan pengetahuan baru dengan konsep yang telah ada pada struktur kognitif peserta didik, sehingga terjadi belajar bermakna. Hal-hal tersebut diperkuat oleh penelitian Luritawaty et al (2015) menyatakan bahwa kemampuan pemecahan masalah matematis peserta didik yang memperoleh pembelajaran advance organizer lebih baik daripada peserta didik yang memperoleh pembelajaran konvensional.

Patut diduga dengan menggunakan model pembelajaran generatif berbantuan scaffolding dan model pembelajaran generatif berbantuan advance organizer diharapkan dapat meningkatkan kemampuan pemecahan masalah fisika peserta didik. Selain itu, belum adanya penggunaan model pembelajaran generatif yang digabungkan dengan scaffolding dan model pembelajaran generatif berbantuan advance organizer, serta dari beberapa penelitian terkait masih pada mata pelajaran bahasa, kimia, biologi dan matematika sehingga peneliti merasa tertarik untuk melakukan penelitian pada bidang studi fisika. Berdasarkan pertimbangan tersebut, maka penggunaan model pembelajaran generatif yang digabungkan dengan scaffolding dan advance organizer diduga tepat untuk digunakan di SMA Negeri 4 Mataram. Hal tersebut didukung dari hasil observasi awal pada sekolah tersebut. Peneliti berharap penggunaan model pembelajaran generatif berbantuan scaffolding dan advance organizer mampu meningkatkan kemampuan pemecahan masalah peserta didik pada pembelajaran fisika di tingkat sekolah menengah atas.

\section{METODE PENELITIAN}

Desai dari penelitian kuasi eksperimen ini menggunakan non-equivalent control group design with pre-test-and post-test. Suatu penelitian memiliki beberapa variabel penelitian sehingga pembaca dapat mengetahui alur dari sebuah eksperimen. Penelitian ini melibatkan variabel bebas yaitu model pembelajaran generatif, scaffolding dan advance organizer, variabel terikat yaitu kemampuan pemecahan masalah fisika, dan variabel kontrol yaitu waktu, guru yang mengajar dan materi ajar.

Penelitian ini dilakukan di SMA Negeri 4 Mataram. Populasi penelitian adalah 4 kelas berisi 148 peserta didik. Sampel penelitian adalah 66 peserta didik yang dibagi dalam dua kelas yaitu masing-masing 33 peserta didik untuk kedua kelas. Pemilihan sampel ditentukan dengan purposive sampling, dimana harus ada sebab khusus dalam pengambilan sampel. Sebab peneliti mengambil kelas XI IPA 2 dan kelas XI IPA 3 sebagai sampel adalah karena dari 4 kelas XI pada sekolah tersebut, nilai rata-rata UTS kelas XI IPA 2 dan kelas XI IPA 3 memiliki perbedaan yang sangat tipis, secara berturut-turut nilainya adalah 63,20 dan 63,25 . Nilai tersebut kurang dari KKM yaitu 70,00.

Instrumen yang digunakan adalah tes kemampuan pemecahan masalah. Teknik pengumpulan data berupa tes tertulis berbentuk soal uraian. Tes kemampuan pemecahan masalah berjumlah 8 soal. Indikator yang digunakan dalam tes kemampuan pemecahan masalah ini mengacu pada Isakses dan Treffinger (1985) dalam Amer (2005) menyatakan bahwa model pemecahan masalah (problem-solving) kreatif memiliki enam 
tahap, yaitu (1) menemukan kekacauan (mess finding), (2) menemukan data (data finding), (3) menemukan masalah (problem finding), (4) menemukan ide (idea finding), (5) menemukan solusi (solution finding), dan (6) menemukan dukungan (acceptance finding). Instrumen tes kemampuan pemecahan masalah sebelum digunakan harus memenuhi beberapa syarat yaitu uji validitas, reliabilitas, tingkat kesukaran soal dan daya beda. Uji analisis data menggunakan uji-t polled varian dengan taraf signifikan $5 \%$ dan derajat kebebasan $\left(n_{1}+n_{2}\right)-2$. Data hasil kemampuan pemecahan masalah yang diperoleh dianalisis dengan $\mathrm{N}$-gain untuk mengetahui peningkatan antara kedua kelas.

\section{HASIL DAN PEMBAHASAN}

Penelitian ini bertujuan untuk mengetahui apakah ada pengaruh model pembelajaran generatif berbantuan scaffolding dan advance organizer terhadap kemampuan pemecahan masalah fisika peserta didik SMA kelas XI. Penelitian dilakukan dengan memberikan perlakuan berupa penerapan model pembelajaran generatif berbantuan scaffolding pada kelas generatif + scaff (XI IPA 2) dan perlakuan berupa penerapan model pembelajaran generatif berbantuan advance organizer pada kelas generatif + AO (XI IPA 3). Kedua kelas diberikan perlakuan selama tiga kali pertemuan dengan alokasi waktu setiap pertemuan selama 90 menit (2 jam pelajaran). Sebelum diberikan perlakuan kedua kelas diberikan tes awal kemampuan pemecahan masalah yang bertujuan untuk mengetahui kemampuan awal peserta didik pada kedua kelas.

Penelitian yang sudah dilakukan di SMAN 4 Mataram berlangsung kurang lebih satu bulan. Penelitian ini mengukur ranah kognitif yaitu $\mathrm{C} 1$ sampai C6 untuk tes kemampuan pemecahan masalah yang bertujuan untuk mengetahui pengaruh pembelajaran fisika menggunakan model pembelajaran generatif berbantuan scaffolding dan advance organizer terhadap kemampuan pemecahan masalah fisika peserta didik kelas XI. Data tentang hasil kemampuan peserta didik sebelum dan sesudah perlakuan diperoleh peneliti melalui tes awal (pre-test) dan tes akhir (post-test).

Kemampuan awal kemampuan pemecahan masalah peserta didik baik kelas generatif + scaff maupun kelas generatif $+\mathrm{AO}$ berdasarkan hasil tes awal masih rendah. Hal ini terlihat dari nilai ratarata tes kemampuan pemecahan masalah masingmasing kelas, yaitu untuk kelas generatif + scaff adalah 31,97 dan untuk kelas generatif $+\mathrm{AO}$ adalah 32,16 , dan jika dibandingkan dengan nilai KKM, rata-rata tersebut dikategorikan tidak tuntas. Hal ini disebabkan karena kurangnya kemampuan awal peserta didik untuk menghubungkan pengetahuan yang lama dengan pengetahuan baru dan bagaimana mengkonstrusikan pengetahuan tersebut, sehingga solusi yang diterapkan oleh peneliti adalah melaksanakan pembelajaran menggunakan model generatif dengan berbantuan scaffolding dan advance organizer.

Tes kemampuan pemecahan masalah yang digunakan adalah tes essai yang terdiri dari 8 soal. Adapun deskripsi statistik meliputi rata-rata, standar deviasi, varian, dan jumlah peserta didik berdasarkan pembelajaran yang digunakan berdasarkan ranah yang dinilai, yaitu ranah kognitif, maka kemampuan yang diukur adalah kemampuan pemecahan masalah peserta didik. Pengambilan data untuk data kemampuan awal dan akhir dilakukan dengan memberikan tes, yaitu pretest dan post-test. Pada hasil uji coba instrumen terdapat 8 soal yang diterima, terdapat 8 soal yang valid dan reliable. Peneliti menyimpulkan untuk mengambil 8 soal tersebut untuk diberikan ke peserta didik pada saat melakukan tes awal dan tes akhir.

Hasil penelitian yang sudah dilakukan menggambarkan bahwa kemampuan akhir kemampuan pemecahan masalah peserta didik berbeda dengan kemampuan awalnya. Kelas generatif + scaff maupun kelas generatif $+\mathrm{AO}$ mengalami peningkatan. Peningkatan kelas generatif $+\mathrm{AO}$ lebih baik daripada peningkatan pada kelas generatif + scaff, namun perbedaan peningkatannya sangat tipis, sehingga dapat dikatakan bahwa model pembelajaran generatif berbantuan scaffolding dan advance organizer sama-sama berhasil meningkatkan kemampuan pemecahan masalah fisika peserta didik dengan sangat baik. Pada kegiatan pembelajaran kelas generatif + scaff dan 2 (dengan menerapkan model pembelajaran generatif) terkandung empat sintaks, yaitu persiapan, pemfokusan, tantangan dan aplikasi. Keempat sintaks dalam pembelajaran ini terkandung dalam kegiatan pembelajaran yang 
dilakukan. Kelas generatif + scaff mendapat bantuan LKPD scaffolding yang memberikan bantuan berupa jawaban yang menuntun peserta didik agar dapat memecahkan masalahnya sendiri, jawaban tersebut terus dikurangi sampai akhirnya peserta didik tersebut dapat memecahkan masalahnya sendiri. Bantuan berupa advance organizer yang diberikan pada kelas generatif $+\mathrm{AO}$ yaitu berupa peta konsep di awal pembelajaran, sehingga peserta didik dapat mengetahui mengenai gambaran keseluruhan dalam setiap pertemuan. Kedua hal tersebut ternyata sangat efektif dalam meningkatkan kemampuan pemecahan masalah fisika peserta didik.

Pengaruh perlakuan dapat diketahui dengan menggunakan uji t. Sebelum melakukan uji-t pada hasil kemampuan awal dan kemampuan akhir, dilakukan terlebih dahulu uji normalitas dan uji homogenitas. Uji ini dilakukan bertujuan utuk memperoleh sampel yang berdistribusi normal, yaitu untuk uji normalitas dan uji homogenitas bertujuan untuk mengetahui apakah varians kelas generatif + scaff dan kelas generatif $+\mathrm{AO}$ sama.

Hasil tes kemampuan pemecahan masalah menunjukkan adanya peningkatan yang signifikan pada tes akhir kelas generatif + scaff yang menggunakan bantuan scaffolding. Pada hasil penelitian data kemampuan pemecahan masalah diperoleh rata-rata kelas generatif + scaff yaitu 77,5 dengan nilai tertinggi 95 dan nilai terendah 60 . Nilai rata-rata tes awal dengan tes akhir KPM sangat jauh berbeda yaitu dari 31,97 menjadi 77,5. Hal tersebut menunjukkan bahwa perlakuan yang diberikan pada kelas generatif + scaff yang menggunakan bantuan scaffolding berdampak positif terhadap peningkatan KPM. Hasil penelitian ini sejalan dengan penelitian sebelumnya, Septriani et al (2014) menyatakan bahwa scaffolding dapat meningkatkan kemampuan keterampilan menulis teks recount berbahasa inggris dan kreativitas peserta didik.

Kelas generatif $+\mathrm{AO}$ memperoleh nilai ratarata sebesar 77,386 dengan nilai tertinggi 97,5 dan nilai terendah 46,25 . Nilai rata-rata tersebut sangat berbeda dengan nilai pada tes awal yaitu 32,16. Nilai rata-rata tersebut menunjukkan bahwa ada peningkatan yang signifikan setelah kelas generatif + AO diberikan perlakuan berupa bantuan advance organizer, sehingga dapat diketahui bahwa advance organizer berpengaruh positif terhadap peningkatan kemampuan pemecahan masalah fisika peserta didik. Hasil penelitian ini sejalan dengan penelitian sebelumnya. Penelitian terkait dengan advance organizer antara lain dilakukan oleh Tasiwan et al (2014) menyatakan bahwa model advance organizer berbasis proyek dapat meningkatkan kemampuan analisis-sintesis peserta didik dalam aspek menguraikan, mengkategorikan, mengidentifikasi, merumuskan pernyatan, merekonstruksi, menentukan dan menganalisa konsep. Luritawaty et al (2015) menyatakan bahwa kemampuan pemecahan masalah matematis peserta didik yang memperoleh pembelajaran advance organizer lebih baik daripada peserta didik yang memperoleh pembelajaran konvensional.

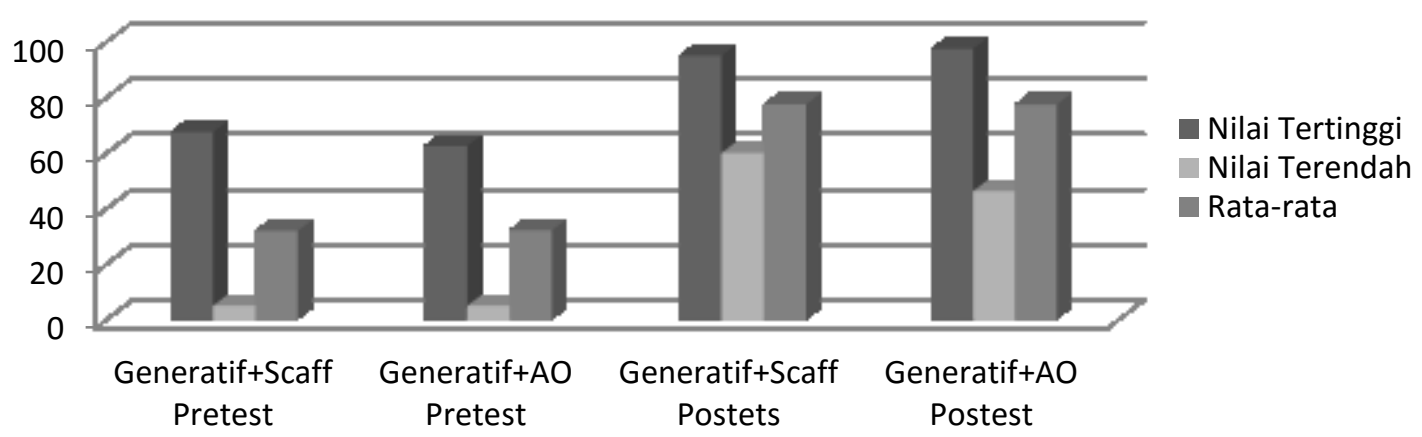

Diagram 1 Hasil Tes Kemampuan Pemecahan Masalah Pada Kedua Kelas

Diagram 1 menunjukkan perbedaan nilai tertinggi, nilai terendah dan nilai rata-rata dari masing-masing kelas. Terlihat bahwa perbedaan antara nilai tertinggi dan nilai terendah antara kedua kelas tidak jauh berbeda. Rata-rata nilai tes kemampuan pemecahan masalah antara kedua kelas juga tidak berbeda secara signifikan.

Pembelajaran bermakna merupakan suatu proses mengaitkan informasi baru pada konepkonsep relevan yang terdapat dalam struktur 
kognitif seseorang. Konsep ini menjelaskan bahwa dalam diri seorang pelajar sudah ada organisasi dan kejalasan tentang pengetahuan dibidang subjek tertentu. Organisasi yang dimaksud sebagai struktur kognitif dan percaya bahwa struktur ini menentukan kemampuan pelajar untuk menangani berbagai ide dan hubungan baru. Oleh karena itu, dengan diberikan bantuan advance organizer peserta didik melakukan belajar bermakna, karena dapat menghubungkan antara pengetahuan baru yang telah didapat, dengan pengetahuan lama, sesuai dengan teori Ausubel. Menurut Ausubel (1968) belajar dengan penemuan yang bermakna yaitu mengaitkan pengetahuan yang telah dimilikinya dengan materi pelajaran yang dipelajari itu. Atau sebaliknya, siswa terlebih dahulu menmukan pengetahuannya dari apa yang ia pelajari kemudian pengetahuan baru tersebut ia kaitkan dengan pengetahuan yang sudah ada. Hal tersebut dapat menjelaskan bahwa, walau advance organizer hanya diberikan satu kali pada awal pembelajaran, namun hasilnya hampir sama dengan yang diberikan scaffolding (secara terus-menerus), karena tercipta belajar bermakna pada kelas yang diberikan bantuan advance organizer.

Setelah diuji, ternyata kedua kelas homogen dan terdistribusi normal baik pada tes awal maupun tes akhir, artinya kemampuan awal peserta didik pada kedua kelas tersebut sama, dan setelah diberi perlakuan yang berbeda data yang di dapat tetap homogen dan terdistribusi normal. Berdasarkan hasil tersebut dapat diketahui bahwa walaupun perlakuan yang diberikan pada kedua kelas tersebut berbeda, namun menunjukkan hasil yang relatif sama, yaitu sama-sama memberikan peningkatan yang positif pada kemampuan pemecahan masalah peserta didik. Kelas yang diberikan perlakuan menggunakan bantuan scaffolding memiliki peningkatan yang lebih baik dibandingkan dengan kelas yang diberikan bantuan advance organizer hal tersebut terjadi karena scaffolding diberikan sepanjang kegiatan pembelajaran sedangkan advance organizer hanya diberikan di awal saja.
Walaupun demikian, perbedaan peningkatannya sangatlah tipis sehingga dapat diatakan bahwa tidak ada pebedaan yang signifikan dari hasil peningkatan KPM pada kedua kelas.

Perbedaan peningkatan kemampuan pemecahan masalah pada kedua kelas terjadi karena peserta didik cenderung lebih baik dalam menyelesaikan masalah ketika mereka mendapatkan bantuan secara terus menerus hingga mereka dapat menyelesaikannya sendiri. Apabila bantuan hanya diberikan di awal, hal tersebut cenderung membuat peserta didik akan sedikit kebingungan bila mendapat hambatan ditengah perjalanan. Namun, jika gambaran tersebut berupa peta konsep yang jelas dan runtut, peserta didik akan mendapatkan poin-poin penting dalam menyelesaikan masalah tersebut. Pemberian advance organizer di awal pembelajaran ternyata sangatlah efektif, karena dapat memberikan gambaran dan jalan tesendiri bagi peserta didik untuk menyelesaikan masalah yang diberikan, sehingga baik advance organizer ataupun scaffolding memiliki dampak yang sangat positif dalam meningkatkan kemampuan pemecahan masalah peserta didik. Oleh karena itu, hasil penelitian ini menunjukkan perbedaan peningkatan yang sangat tipis antara kedua kelas. Kedua perlakuan ternyata memiliki dampak yang sama baiknya sehingga tidak ada pengaruh yang signifikan dari kedua perlakuan tersebut.

Setelah dilakukan uji hipotesis dengan menggunakan uji statistik (uji-t polled varian), didapatkan harga $t_{\text {hitung }}=0,12545$. Harga ini lebih kecil dari harga $t_{\text {tabel }}=1,99714$. Hal ini berarti tidak ada pengaruh antara kemampuan pemecahan masalah fisika peserta didik yang diberikan perlakuan berupa penerapan model pembelajaran generatif berbantuan scaffolding dengan kelas yang diberikan perlakuan berupa penerapan model pembelajaran generatif berbantuan advance organizer, sehingga terbukti bahwa tidak ada pengaruh dari kedua perlakuan tersebut. 
Tabel 1 Persentase Indikator Kemampuan Pemecahan Masalah

\begin{tabular}{lccccccc}
\hline \multicolumn{1}{c}{ Kelas } & Kemampuan & IPM-1 & IPM-2 & IPM-3 & IPM-4 & IPM-5 & IPM-6 \\
\hline Generatif + Scaff & \multirow{2}{*}{ Awal } & $35 \%$ & $35 \%$ & $60 \%$ & $48 \%$ & $19 \%$ & $13 \%$ \\
Generatif + AO & & $38 \%$ & $38 \%$ & $58 \%$ & $46 \%$ & $20 \%$ & $16 \%$ \\
Generatif + Scaff & \multirow{2}{*}{ Akhir } & $86 \%$ & $86 \%$ & $91 \%$ & $86 \%$ & $70 \%$ & $66 \%$ \\
Generatif + AO & & $93 \%$ & $93 \%$ & $97 \%$ & $92 \%$ & $66 \%$ & $57 \%$ \\
\hline
\end{tabular}

Berdasarkan pada hasil persentase nilai ratarata KPM tes awal dan tes akhir kelas generatif + scaff dan generatif $+\mathrm{AO}$, didapat bahwa persentase rata-rata IPM-1 sampai dengan IPM-6 tes awal kelas generatif + scaff berturut-turut yaitu $35 \%$, $35 \%, 60 \%, 48 \%, 19 \%$ dan $13 \%$, sedangkan kelas generatif + AO yaitu 38\%, 38\%, 58\%, 46\%, 20\% dan $16 \%$. Kemudian untuk rata-rata KPM tes akhir kelas generatif + scaff berturut-turut sebesar $86 \%$, $86 \%, 91 \%, 86 \%, 70 \%$ dan $66 \%$, sedangkan kelas generatif + AO yaitu sebesar 93\%, 93\%, 97\%, 92\%, $66 \%$ dan $57 \%$.

Berdasarkan persentase KPM pada tes awal dapat diketahui bahwa pada IPM-1 dan IPM-2 mendapat persentase KPM dalam kategori rendah untuk kelas generatif + scaff dan kelas generatif + AO. IPM-3 dan IPM-4 termasuk dalam kategori sedang untuk kedua kelas. Kemudian untuk IPM-5 dan IPM-6 masih tergolong sangat rendah untuk kelas generatif + scaff dan 2 .

Setelah diberikan perlakuan baik pada kelas generatif + scaff maupun kelas generatif $+\mathrm{AO}$, terjadi peningkatan yang cukup tinggi pada persentase skor rata-rata KPM. Tabel 1 menunjukkan persentase skor rata-rata tes akhir kemampuan pemecahan masalah. IPM-1 sampai IPM-4 termasuk dalam kategori sangat tinggi untuk kelas generatif + scaff dan kelas generatif $+\mathrm{AO}$. IPM-5 dan IPM-6 termasuk dalam kategori tinggi untuk kedua kelas. Oleh karena itu, terlihat jelas bahwa terjadi peningkatan persentase IPM secara signifikan dari tes awal, serta peningkatan persentase KPM pada kedua kelas relatif hampir sama. Hal trsebut menandakan bahwa terjadi peningkatan positif setelah diberi perlakuan pada kedua kelas. IPM-5 (menemukan solusi) dan IPM-6 (menemukan dukungan) relatif lebih rendah dibandingkan IPM lain, hal tersebut dikarenakan kedua IPM tersebut memiliki tingkat kesulitan yang lebih, atau merupakan IPM dengan taraf berfikir tingkat tinggi. Persentase skor rata-rata pada kelas generatif + scaff lebih tinggi pada IPM-5 dan IPM-
6 daripada kelas generatif + AO. Namun, kelas generatif $+\mathrm{AO}$ memiliki persentase skor rata-rata yang lebih tinggi pada IPM-1 sampai IPM-4 dibandingkan dengan kelas generatif + scaff. Hal tersebut terjadi karena kelas generatif + scaff lebih banyak dituntun dalam menyelesaikan masalah sehingga lebih mudah dalam mencari solusi dan dukungan yang tepat, sedangkan untuk kelas generatif $+\mathrm{AO}$ harus mencari sendiri solusi yang tepat agar dapat menyelesaikan masalah. Selain itu, advance organizer merupakan bantuan di awal sehingga peserta didik lebih mudah dalam menemukan masalah dan ide dengan bantuan peta konsep sedangkan dalam mencari solusi, menggunakan bantuan tersebut akan lebih sulit karena harus mencari sendiri sampai menemukan solusi dan dukungan hingga pembelajaran menjadi bermakna bagi peserta didik tersebut.

Hasil Penelitian menunjukkan bahwa indikator pemecahan masalah yang lebih unggul dibanding IPM lainnya adalah IPM-3 (menemukan masalah) dan IPM-4 (menemukan ide). IPM-5 dan IPM-6 masih tergolong rendah, hal tersebut terjadi karena meski peserta didik telah mampu menemukan masalah dan menemukan ide yang tepat, namun belum dapat menuangkan ide tersebut kedalam solusi yang benar dan belum bisa menentukan dukungan yang relevan dengan ide tersebut. IPM-6 memiliki persentase yang rendah disebabkan karena rata-rata peserta didik masih malas dalam membaca dan mencari referensi yang tepat sebagai dukungan. Akibatnya, diperlukan penekanan yang lebih pada setiap indikator agar masing-masing indikator memiliki perolehan persentase yang maksimal.

Temuan dalam penelitian ini memperkuat beberapa penelitian sebelumnya diantaranya adalah penelitian yang dilakukan Tan et al (2001) menyatakan bahwa kemampuan kognitif dan pedagogik memiliki hubungan antara pembelajaran generatif dan berpikir tingkat tinggi yang dapat ditinjau secara singkat. Serta dalam penelitian lain, 
Ulusoy \& Onen (2014) menyatakan bahwa aktivitas pembelajaran berbasis konteks menggunakan model pembelajaran generatif menimbulkan motivasi peserta didik pada pembelajaran kimia bertambah baik dan sikap praktik kimia meningkat kea rah yang baik berdasarkan tingkatan tes yang diberikan. Penelitian Juani et al (2014) menyatakan bahwa kemampuan penalaran matematika peserta didik kelas XI SMK yang diajar dengan model pembelajaran generatif lebih tinggi daripada peserta didik yang diajar dengan model pembelajaran matematika knisley. Septriani et al (2014) menyatakan bahwa scaffolding dapat meningkatkan kemampuan keterampilan menulis teks recount berbahasa inggris dan kreativitas peserta didik. Luritawaty et al (2015) menyatakan bahwa kemampuan pemecahan masalah matematis peserta didik yang memperoleh pembelajaran advance organizer lebih baik daripada peserta didik yang memperoleh pembelajaran konvensional. Hasil penelitian tersebut membuktikan penggunaan model pembelajaran generatif berbantuan scaffolding dan advance organizer dalam pembelajaran langsung berpengaruh positif terhadap kemampuan pemecahan masalah fisika pada peserta didik.

Berdasarkan teori yang telah ada, hasil penelitian sebelumnya dan hasil penelitian peneliti terbukti memiliki kecocokan. Hasil penelitian yang menunjukkan bahwa tidak ada pengaruh model pembelajaran generatif berbantuan scaffolding dan advance organizer terhadap kemampuan pemecahan masalah fisika peserta didik telah sesuai dengan teori yang telah dijabarkan sebelumnya. Oleh karena itu, dapat dikatakan bahwa perlakuan pada penelitian ini dapat meningkatkan kemampuan pemecahan masalah fisika peserta didik, sejalan dengan penelitian-penelitian sebelumnya dan tidak ada pengaruh model pembelajaran generatif berbantuan scaffolding dan advance organizer terhadap kemempuan pemecahan masalah fisika peserta didik SMA kelas XI.

\section{KESIMPULAN}

Berdasarkan uji hipotesis, dapat disimpulkan bahwa tidak ada pengaruh kemampuan pemecahan fisika peserta didik antara yang diberikan perlakuan berupa penerapan model pembelajaran generatif berbantuan scaffolding dengan kelas yang diberikan perlakuan berupa penerapan model pembelajaran generatif berbantuan advane organizer. Hal tersebut terjadi karena peningkatan kemampuan pemecahan masalah fisika kedua kelas hampir sama. Kedua perlakuan yang diberikan ternyata memberikan dampak yang sama baiknya sehingga meningkatkan kemampuan pemecahan masalah peserta didik. Oleh karena itu, dapat dikatakan bahwa kedua perlakuan tersebut berpengaruh positif terhadap peningkatan kemampuan pemecahan masalah fisika peserta didik SMAN 4 Mataram kelas XI IPA 2 dan XI IPA 3.

\section{DAFTAR PUSTAKA}

Amer, A., (2005). Analytical Thinking. Cairo: Center of Advancenent of Postgraduate Studies and Research in Engineering Sciences, Cairo University (CAPSCU), 114.

Ausubel, D.P. 1968. Educational Psychology: A Cognitive View. New York: Holt, Rinehart, and Winston.

Gunawan. 2015. Model Pembelajaran Sains Berbasis ICT. Mataram: FKIP UNRAM.

Gunawan., Harjono, A., dan Sutrio. 2015. Multimedia Interaktif dalam Pembelajaran Konsep Listrik bagi Calon Guru. Jurnal Pendidikan Fisika dan Teknologi. 1 (1): 9.

Hamdani, D., Kurniati, E., dan Sakti, I. 2012. Pengaruh Model Pembelajaran Generatif dengan Menggunakan Alat Peraga Terhadap Pemahaman Konsep Cahaya Kelas VIII di SMPN 7 Kota Bengkulu. Jurnal Exacta. 10 (1): 80-82.

Juani, A., Salsabila, E., dan Irawan, B. 2014. Perbandingan Kemampuan Penalaran Matematika antara Siswa yang diajar Menggunakan Model Pembelajaran Generatif dan Model Pembelajaran Matematika Knisley (Mpmk) Pada SMKN 26 Jakarta. JMAP. 13 (1): 48.

Luritawaty, Irena P., dan Nuraeni, R. 2015. Model Advance Organizer dalam Pembelajaran Matematika untuk Meningkatkan Kemampuan Pemecahan Masalah Matematis Siswa. Jurnal Pendidikan Matematika. 6 (1): 13-19.

Rahmatiah, R., \& Kusairi, S. (2017). Pengaruh Scaffolding Konseptual dalam Pembelajaran Group Investigation 
Terhadap Prestasi Belajar Fisika Siswa SMA dengan Pengetahuan Awal Berbeda. Jurnal Pendidikan Fisika dan Teknologi, 2(2), 45-54.

Septriani, N., Irwan, dan Meira. 2014. Pengaruh Pendekatan Scaffolding terhadap Kemampuan Pemahaman Konsep Matematika Siswa Kelas VIII SMP Pertiwi 2 Padang. Jurnal Pendidikan Matematika. 3 (3): 17-21.

Sugiana, I. N., Harjono, A., Sahidu, H., \& Gunawan, G. (2017). Pengaruh Model Pembelajaran Generatif Berbantuan Media Laboratorium Virtual Terhadap Penguasaan Konsep Fisika Siswa pada Materi Momentum dan Impuls. Jurnal Pendidikan Fisika dan Teknologi, 2(2), 61-65.
Tan, W.C., Aris, B., and Abu, S. 2006. GLOTT Model: A pedagogically-enriched design framwork of learning environment to improve higher order thinking skills. $A A C E$ Journal, 14(2): 139-153.

Tasiwan, Nugroho, da Hartono. 2014. Pengaruh Advance Organizer Berbasis Proyek Terhadap Kemampuan Analisis-Sintesis Siswa. Jurnal Pendidikan Fisika Indonesia. 10 (1): 1-8.

Ulusoy, F. M., and Onen, A. S. 2014. A Research on the Generative Learning Model Supported by Context-Based Learning. Eurasia Journal of Mathematics, Science \& Technology Education. 10(6): 537-546. 